\title{
Critical role of NF-KB in pancreatic cancer
}

\author{
Lakshmi Prabhu', Rasika Mundade1, Murray Korc ${ }^{2,3}$, Patrick J. Loehrer ${ }^{4}$, Tao Lu,3,5 \\ ${ }^{1}$ Department of Pharmacology and Toxicology, Indiana University School of Medicine, Indianapolis, IN, USA \\ ${ }^{2}$ Department of Medicine, Joseph E. Walther Hall, Indianapolis, IN 46202, USA \\ ${ }^{3}$ Department of Biochemistry and Molecular Biology, Indiana University School of Medicine, Indianapolis, IN, USA \\ ${ }^{4}$ Division of Hematology and Oncology, Indiana Cancer Pavilion, Indianapolis, IN, USA \\ ${ }^{5}$ Department of Medical and Molecular Genetics, Indiana University School of Medicine, Indianapolis, IN, USA \\ Correspondence to: \\ Tao Lu, e-mail: lut@iupui.edu \\ Keywords: NF-KB, pancreatic cancer \\ Received: August 26, $2014 \quad$ Accepted: October 23, $2014 \quad$ Published: December 10, 2014
}

\begin{abstract}
Pancreatic ductal adenocarcinoma (PDAC) is one of the deadliest cancers, and in spite of intense efforts there are limited therapeutic options for patients with PDAC. PDACs harbor a high frequency of Kras mutations and other driver mutations that lead to altered signaling pathways and contribute to therapeutic resistance. Importantly, constitutive activation of nuclear factor KB (NF-KB) is frequently observed in PDAC. An increasing body of evidence suggests that both classical and non-classical NF-kB pathways play a crucial role in PDAC development and progression. In this review, we update the most recent advances regarding different aspects of NF-KB involvement in PDAC development and progression, emphasizing its potential as a therapeutic target and the need to discover pathway-specific cytosolic NF-KB regulators which could be used to design novel therapeutic strategies for PDAC.
\end{abstract}

\section{INTRODUCTION}

NF- $\kappa$ B superfamily and its signaling pathways

The nuclear factor $\kappa \mathrm{B}(\mathrm{NF}-\mathrm{\kappa B})$ transcription factor was discovered when it was observed that it binds to the enhancer element of the immunoglobulin $\kappa$ light-

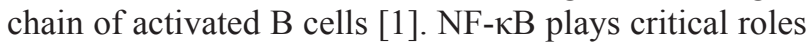
in inflammation, cell proliferation and differentiation, immune response and cancer [2]. There are five proteins in the mammalian NF- $\mathrm{kB}$ family: RelA (p65), RelB, c-Rel, p50/p105 and p52/p100. They all share a Rel homology domain (RHD) in their N-terminus, which results in their classification as NF- $\mathrm{kB} / \mathrm{Rel}$ proteins. The RHD is essential for dimerization as well as binding to $\kappa \mathrm{B}$ cognate DNA elements. NF- $\kappa \mathrm{B}$ activity is primarily regulated by interaction with a family of inhibitors called I $\kappa \mathrm{Bs}$ (inhibitor of $\kappa \mathrm{B}$ ) proteins. I $\mathrm{B}$ proteins mask the nuclear localization signals (NLS) of NF- $\mathrm{KB}$ proteins and keep them sequestered in a latent, inactive complex in the cytoplasm.

There are two different pathways involving $\mathrm{NF}-\kappa \mathrm{B}$ : the classical (or canonical) and non-classical (or non-canonical) pathways. In the classical NF- $\mathrm{kB}$ activation pathway, upon receiving extracellular signals such as stress, cytokines, free radicals, or radiation, the IкB kinase (IKK) phosphorylates IкB [3], which then signals the ubiquitination and degradation of $\mathrm{I} \kappa \mathrm{B}$ by the proteasome system. The p65/p50 heterodimer of $\mathrm{NF}-\kappa \mathrm{B}$ is then released and can rapidly enter the nucleus to 'turn on' the expression of a variety of $\kappa \mathrm{B}$-dependent genes. By contrast, the non-classical pathway is mediated via p100/RelB complexes that are normally inactive in the cytoplasm. Signaling through a subset of receptors, such as LT $\beta$ R (lymphotoxin $\beta$ receptor) and CD40, activates the NF- $\mathrm{KB}$-inducing kinase (NIK), which in turn activates IKKa complexes that phosphorylate $\mathrm{C}$-terminal residues in p100. Phosphorylation of p100 leads to its ubiquitination and proteasomal processing to $\mathrm{p} 52$, leading to the formation of $\mathrm{p} 52 / \mathrm{RelB}$ complexes that translocate to the nucleus and induce target gene expression.

Correlation between NF-кB with different types of cancer

Constitutive NF- $\mathrm{KB}$ activation has been noted in $95 \%$ of all cancers [4-6]. Oncogenic roles of $\mathrm{NF}-\mathrm{\kappa B}$ include promotion of cell proliferation, control 
of apoptosis, and stimulation of angiogenesis, invasion/ metastasis in cancer cells.

Numerous studies have now documented the role of NF- $\mathrm{kB}$ in the development of solid malignancies. For instance, NF- $\mathrm{kB}$ has been shown to be involved in the development of breast cancer. Thus, constitutive NF- $\kappa \mathrm{B}$ DNA-binding activity is seen in mammary carcinoma cell lines and primary breast cancer cells of human and rodent origin [7]. Furthermore, NF- $\kappa \mathrm{B}$ has been shown to function as a key link between inflammatory bowel disease (IBD) and colorectal cancer (CRC) by regulating inflammatory responses and providing a barrier against extrinsic hazard. Studies with azoxymethane (AOM)/ dextran sodium sulfate (DSS) mouse models of colitisassociated colon cancer (CAC) and animal models carrying a conditional disruption of IKK $\beta$ have been used to show that IKK $\beta$-driven NF-KB activation within intestinal epithelial cells (IECs) is essential for CRC development [8-10]. Another example is the involvement of NF- $\mathrm{KB}$ in melanoma, the most aggressive form of skin carcinoma [11]. It has been demonstrated that upregulation of the NF-KB levels is responsible for both the development and metastasis of melanoma. In addition to solid tumors, since NF- $\kappa \mathrm{B}$ plays a very important role in immune cell function, hyperactive NF- $\mathrm{\kappa B}$ is also frequently associated with the development of leukemia and lymphoma [12].

\section{Role of NF- $\kappa \mathrm{B}$ in pancreatic ductal adenocarcinoma (PDAC)}

It is generally considered that oncogenic Kras is the initiating molecular alteration in PDAC [13-15]. Its importance in PDAC became clearly evident with the generation of the first genetically engineered mouse model (GEMM) of PDAC that truly recapitulated the histological features seen in humans. Thus, $K C$ (stands for Kras;Pdx1-Cre recombinase) mouse carries an oncogenic Kras $\left(\operatorname{Kras}^{\mathrm{G} 12 \mathrm{D}}\right)$ allele that has been knockedin within its own locus and silenced by the insertion of an upstream LoxP-Stop-LoxP (LSL) element [16]. Oncogenic Kras transcription is thus controlled by its endogenous promoter, and the transcript is expressed in early pancreatic progenitors after LSL excision by a pancreas-specific Cre recombinase such as Pdx-1. $K C$ mice develop low grade pancreatic intra-epithelial neoplasia (PanIN) and exhibit areas of acinar to ductal metaplasia (ADM) by 2 months of age [16]. By age 8 to 12 months, $K C$ mice develop PDAC at moderate penetrance [16]. PanIN is a crucial feature of PDAC initiation in humans and GEMMs, and PanIN progression to PDAC is accelerated by loss of tumor suppressor genes such as $p 53, C d k n 2 A$ (cyclin-dependent kinase inhibitor 2A), Smad4 (mothers against decapentaplegic homolog 4), Pten (phosphatase and tensin homolog), or $R b$ (retinoblastoma protein) [17-21].
PDAC exhibits marked resistance to chemotherapy and radiotherapy, a propensity to metastasize, and a dismal 5-year survival rate of 6\% [22-24]. Given the role of NF- $\mathrm{kB}$ in different cancer types, and the fact that $\mathrm{NF}-\kappa \mathrm{B}$ transcriptional factors are constitutively activated in the majority of PDACs, it is likely that NF- $\mathrm{KB}$-driven pathways are involved in the regulation of numerous aspects of PDAC development and progression.

\section{Links between Kras mutation and NF-кB signaling in PDAC}

$\mathrm{NF}-\kappa \mathrm{B}$ is known to be constitutively activated in most PDAC patients [25]. Instances of NF- $\mathrm{KB}$ pathway interacting with concurrent signaling pathways have been recently documented, which might contribute towards the PDAC etiology. For instance, it was shown that the $\operatorname{Kras}^{G 12 D}$ mutation seen in almost all PDAC cases is the main driver of constitutive NF- $\mathrm{kB}$ expression in PanINs and PDACs. As shown in Figure 1, the Kras mutation correlates with overexpression of interleukin-1a (IL-1a), a cytokine that binds to its receptor on the cell surface, through activation of AP-1. AP-1 is a transcription factor that is upregulated in Kras mutated cells and drives IL-a transcription. This leads to the polyubiquitination of tumor necrosis factor (TNF) receptor-associated factor 6 (TRAF6) at lysine 63 (K63). The K63-ubiquitinTRAF6 can be recognized by the K63-ubiquitin-binding activity of NEMO [a component of the IאB kinase (IKK) complex], therefore, recruiting IKK to the cellular surface. This binding activates the IKK complex, which then causes proteasomal degradation of the IKB complex via phosphorylation of I $\mathrm{KB}$. This leads to translocation of $\mathrm{NF}-\kappa \mathrm{B}$ to the nucleus and activation of its target genes. One of its target genes is $p 62$, an adaptor for regulating the turnover of K63-polyubiquitinated proteins. Thus, this generates an autoregulatory loop where NF- $\kappa B$ upregulates $p 62$ expression, which in turn helps to drive NF- $\kappa \mathrm{B}$ activity. Thus, IL-1a acts as a link between the Kras and NF- $\mathrm{kB}$ signaling pathways, which act in concert to drive tumor initiation and progression in PDAC [26].

In the context of Kras-induced PDAC, it has also been shown that NF- $\mathrm{kB}$ and Notch signaling interact to drive a sustained inflammatory response in transformed cells [27]. As a major transcription factor for these inflammatory responses, NF- $\mathrm{kB}$ is found to be activated in Kras-transformed epithelial cells [27]. Its activation further leads to the expression and secretion of many NF- $\mathrm{\kappa B}$ responsive inflammatory cytokines, such as TNF-a. This in turn binds to its receptor to activate the NF- $\kappa B$ pathway through the IKK complex (comprising of IKK1, 2 and 3 subunits) via the classical NF-KB activation pathway. In collaboration with basal Notch signals, NF- $\mathrm{\kappa B}$ activation induced optimal expression of Notchregulated genes Hes 1 (hairy and enhancer of split-1) and Heyl (Hairy/enhancer-of-split related with YRPW motif 


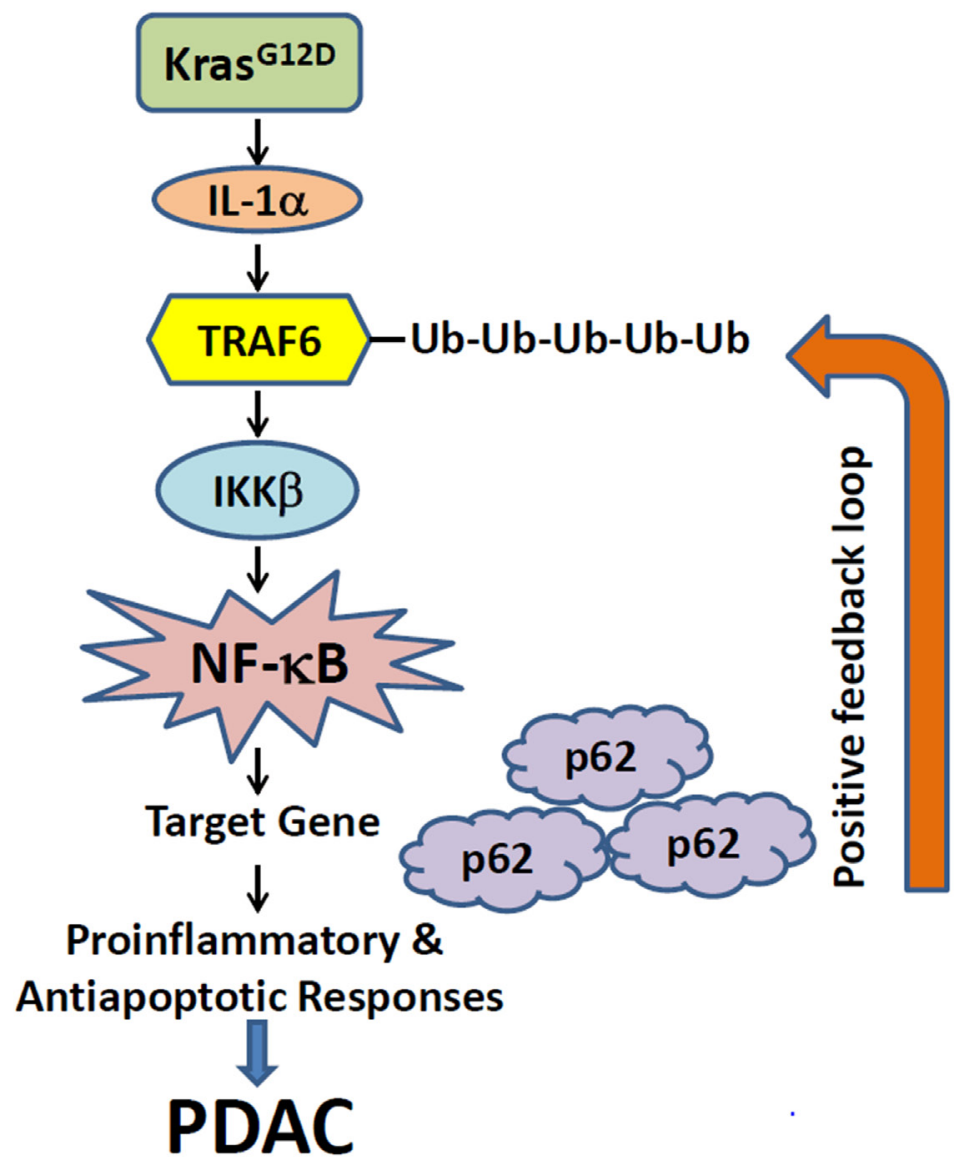

Figure 1: A proposed working model illustrates the potential mechanism through which KrasG12D oncogenic signaling induces positive feedback loops of IL-1a and p62 to sustain constitutive IKK $\beta / N F-\kappa B$ activation in PDAC development. KrasG12D induces the secretion of IL-1a, which further leads to the ubiquitination of TRAF6 and activation of IKK $\beta$. This would further activate NF- $\kappa \mathrm{B}$ to induce its target genes, including $p 62$. The p62 protein in turn will positively regulate TRAF6 ubiquitination and lead to the constitutive NF-кB activation and PDAC development (Adapted from Ref. 26).

protein 1). Mechanistically, TNF-a stimulation resulted in phosphorylation of histone $\mathrm{H} 3$ at the Hes 1 promoter, and this signal was lost with $I k k 2$ gene deletion. Hes 1 suppresses expression of the anti-inflammatory nuclear receptor Ppary (Peroxisome proliferator-activated receptor gamma). Thus, crosstalk between TNF-a/IKK2 and Notch sustains the intrinsic inflammatory profile of transformed cells. These findings reveal a novel interaction between oncogenic inflammation and a major cell fate pathway and show how Kras, NF- $\mathrm{B}$ and Notch pathways can cooperate to promote cancer progression in PDAC cells.

\section{NF-кB and cytokine/chemokine secretion in PDAC}

In addition to its role in the Kras-induced PDAC, $\mathrm{NF}-\kappa \mathrm{B}$ also functions as a key link between pancreatic inflammation and cancer. Chronic pancreatitis is a chronic inflammatory condition in which the pancreas harbor inflammatory cells and macrophages, and exhibits enhanced stroma formation. During their lifetime, patients with chronic pancreatitis exhibit a 16-fold increased risk for developing PDAC [23]. One explanation for this increased propensity to develop PDAC is increased cytokine secretion from intra-pancreatic macrophages. Storz and colleagues showed that macrophages from patients with chronic pancreatitis secrete increased amounts of the pro-inflammatory cytokines, RANTES (regulated on activation normal $\mathrm{T}$ cell expressed and secreted) and TNF-a, which in turn activate NF- $\kappa$ B and promote expression of $\mathrm{NF}-\kappa \mathrm{B}$ target genes such as MMP-9 (Matrix metallopeptidase 9). This mechanism has been proposed to lead to ADM and eventually PanIN formation [28]. Another study has also suggested that transforming growth factor $\beta$ (TGF- $\beta$ ) can activate NF$\kappa \mathrm{B}$ to downregulate the expression of tumor suppressor gene Pten, thereby promoting cell motility in PDAC cell lines, thus suggesting that these pathways might get interlinked in PDAC [29]. Interestingly, the TGF- $\beta$ activated kinase 1 (TAK1) is a key player in the activation 
of NF- $\kappa \mathrm{B}$ in many situations. For example, Shinohara et al [30] recently reported that the CARD-containing MAGUK protein 1 (CARMA1)-TAK1-IKK $\beta$ module is a switch mechanism for NF- $\kappa \mathrm{B}$ activation in $\mathrm{B}$ cell receptor (BCR) signaling. Mutation of the scaffolding protein CARMA1 at serine-578, an IKK $\beta$ target, abrogated not only late TAK1 activity, but also the activation of $\mathrm{NF}-\kappa \mathrm{B}$ in $\mathrm{B}$ cells, suggesting the intimate connection between TAK1 and NF- $\kappa \mathrm{B}$ activation. Previously, we reported that some tumor cell lines secrete high concentrations of TGF- $\beta$ or IL- $1 \beta$. We found that similarly high concentrations of each of these cytokines cross-activate the other pathway: TGF- $\beta$ activates NF- $\kappa$ B, and IL-1 $\beta$ activates the major transcription factor Smads in TGF- $\beta$ pathway. Importantly, TAK1 is required for this important cross-activation. We also found that cross-talk between the TGF- $\beta$ and IL-1 $\beta$ signaling pathways leads to dose-dependent cross-control of gene expression. These interactions provide new insight into biological responses to IL- $1 \beta$ and TGF- $\beta$ in the proximity of tumors that secrete high concentrations of these factors and probably also at sites of inflammation, where the local concentrations of these cytokines are likely to be high [31].

In addition to cytokines, chemokines are also elevated in PDAC cells, and its increase is most likely due to enhanced NF- $\kappa \mathrm{B}$ signaling. For instance, CXCL14 is a chemokine that promotes angiogenesis and tumor growth and its levels are elevated in PDAC [32]. Increased CXCL14 levels have been shown to promote translocation of NF- $\kappa \mathrm{B}$ to the nucleus, thus activating the $N F-\kappa B$ signaling pathway [32].

\section{Other factors that affect NF-KB in PDAC}

Besides cytokines and chemokines, NF- $\kappa \mathrm{B}$ activity can also be affected by other factors, such as microRNAs, posttranslational modifications, and reactive oxygen species (ROS). For example, in normal cells, NF- $\kappa \mathrm{B}$ repressing factor (Nrkf) down regulates NF- $\kappa \mathrm{B}$ expression. However, in PDAC cells, the activity of Nrkf is down regulated by microRNA miR-301a, whose activity is upregulated in PDAC. This downregulation of Nrkf leads to the activation of NF- $\kappa \mathrm{B}$, which in turn promotes miR-301a transcription, generating a positive feedback loop to increase NF- $\kappa \mathrm{B}$ levels. Overall, this contributes to increased tumor formation in mice [33].

Another characteristic observed in PDAC cell lines is global hyper-O-GlcNAcylation, which also relates to $\mathrm{NF}-\kappa \mathrm{B}$. A recent study observed that a direct posttranslational O-GlcNAc modification of the NF- $\kappa \mathrm{B}$ p65 subunit and of the IKK complex promoted phosphorylation of p65 and nuclear localization and activation of the NF- $\mathrm{NB}$ target genes in PC cell lines [34]. Furthermore, ROS have been implicated in tumor development and proliferation in PDAC. RAGE (receptor for advanced glycation endproducts) is a receptor from the immunoglobulin superfamily involved in ROS generation. Activation of $\mathrm{NF}-\kappa \mathrm{B}$ leads to the upregulation of RAGE expression in PDAC cells [35]. Thus, NF- $\kappa \mathrm{B}$ contributes to PC formation by ROS generation via RAGE. Moreover, the role of NF- $\kappa \mathrm{B}$ is not only limited to PC tumor itself, it is also found to play a role in PC-related cachexia (or wasting syndrome) [36].

\section{Non-classical NF- $\kappa$ B pathway in PC}

Although the classical NF- $\kappa \mathrm{B}$ pathway is the key contributor to PDAC development, there is increasing evidence that non-classical pathway also contributes to PDAC progression. For example, Storz's group suggested that the non-classical $N F-\kappa B$ pathway is a source for the high basal NF- $\kappa \mathrm{B}$ activity in PDAC cell lines [37]. They showed that in Panc1 and MiaPaca2 PC cells, increased activity of the p52/RelB NF- $\kappa$ B complex is mediated through stabilization and activation of NF- $\kappa \mathrm{B}$-inducing kinase (NIK). Their group identified proteasomal degradation of TRAF2 as a mechanism by which levels of active NIK are increased in PC cells. Such upregulation of NIK expression and activity levels eventually led to increased proliferation and anchorage-independent growth of PDAC cells [37].

\section{Perspective}

$\mathrm{NF}-\kappa \mathrm{B}$ pathway is emerging as an important player in PDAC. As illustrated in Figure 2, both the classical and non-classical arms of the pathway have been implicated in promoting disease progression through increased cancer cell proliferation, motility, anti-apoptotic and inflammatory signals that aid in metastasis and disease progression. Not only does the pathway itself contribute to disease initiation and progression, it gets even more complicated since NF- $\mathrm{BB}$ interacts with other pathways that are also deregulated in PDAC. This adds to the disruptions in signaling that can be seen in the different PDAC cases.

Numerous inhibitors of the NF- $\mathrm{B}$ pathway have already been described, including small molecules, peptides, small DNA/RNA, viral proteins, natural compounds etc. [38]. The majority of these compounds have not been specifically tested in a PDAC model. However, it would be worth testing the efficacy of these compounds as a therapeutic strategy in PDAC. For instance, curcumin, a common cooking spice and resveratrol, found in red grapes and berries have been shown to inhibit the cytokine expression mediated by $\mathrm{NF}-\kappa \mathrm{B}$ [39]. Curcumin has also been shown to inhibit IKK activity [40]. Compounds derived from flavonoid precursors like chalcones, commonly found in fruits and vegetables were shown to decrease proliferation in human cancer cell lines [41]. Another flavonoid, quercetin interfered with cell cycle progression and induced apoptosis in HeLa cells by inhibiting NF- $\mathrm{KB}$ activity 


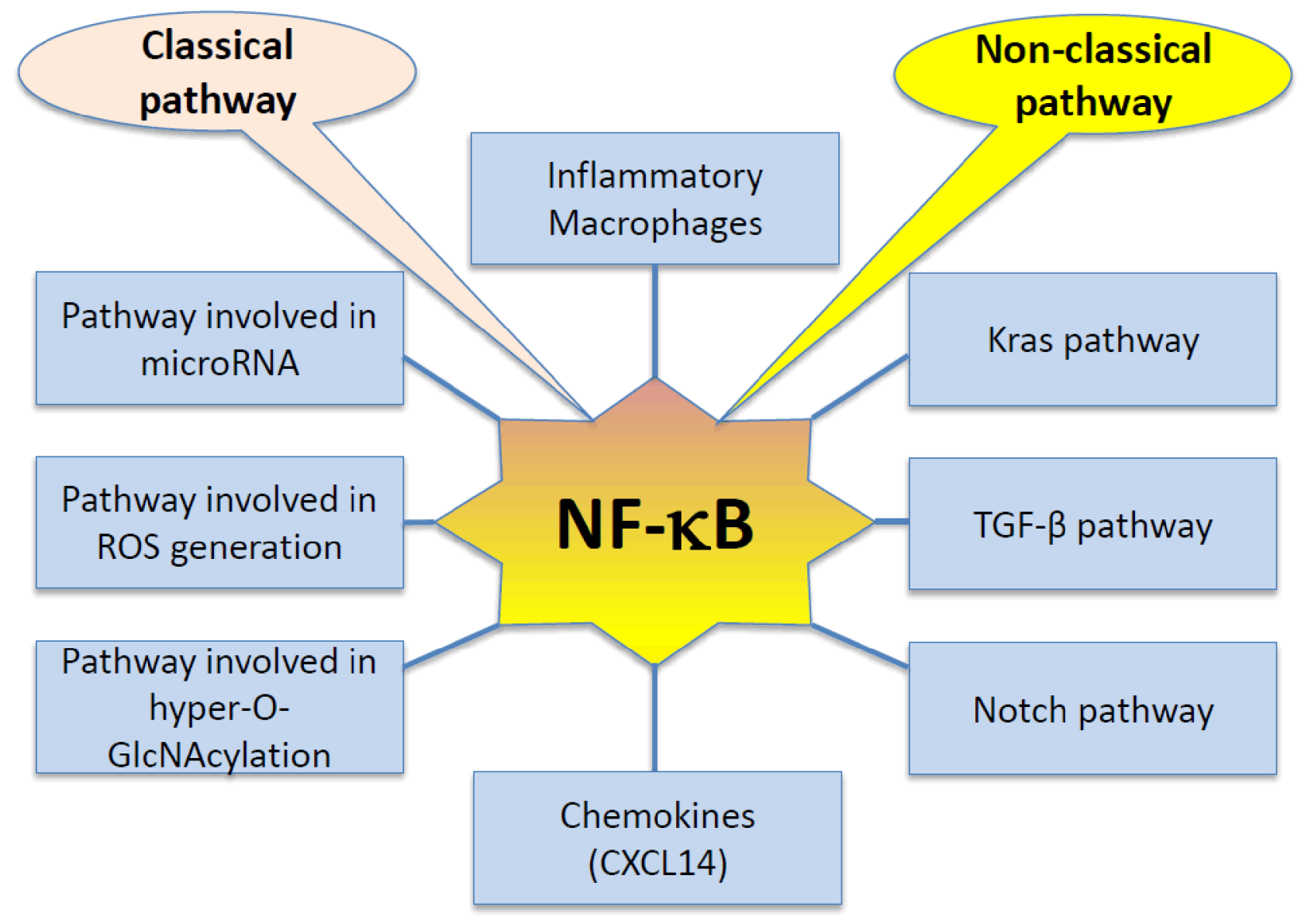

Figure 2: Interactions of NF-кB signaling pathway in pancreatic cancer (PC). As indicated in the diagram, both classical and non-classical NF- $\mathrm{B}$ pathways interact with a number of signaling pathways to remain constitutively activated in pancreatic cancer cells and promotes tumorigenesis and metastasis.

[42]. Small molecule inhibitor screenings have also been effective in detecting compounds like N1241, which inhibits the ability of NF- $\kappa \mathrm{B}$ to bind to DNA and interferes with its activity [43]. Additionally, drugs like bortezemib and thalidomide, which are approved by the US Food and Drug Administration (FDA) for the treatment of multiple myeloma, may also function, in part, by inhibiting NF- $\mathrm{\kappa B}$ activity $[44,45]$.

Several lines of evidence have suggested that inhibition of NF- $\mathrm{KB}$ is effective in PDAC prevention and treatment. For instance, nitric oxide-releasing aspirin (NO-aspirin) represents a novel class of promising chemopreventive agents. Unlike conventional nonsteroidal anti-inflammatory drugs, NO-aspirin seems to be free of adverse effects while retaining the beneficial activities of its parent compound. Recently, Rao et al. [46] evaluated the effect of NO-aspirin on pancreatic carcinogenesis in $\mathrm{Kras}^{\mathrm{G} 12 \mathrm{D}}$ mouse model. Their results revealed that NO-aspirin significantly suppressed pancreatic tumor weight, PDAC incidence, and carcinoma in situ (PanIN-3 lesions) by decreasing $\sim 42 \%$ the expression and activity of cyclooxygenase (COX), a renowned NF- $\mathrm{KB}$-dependent gene. Later on, Streicher et al. further carried out casecontrol study of aspirin use and risk of pancreatic cancer [47]. Moreover, since the NF-kB pathway may also contribute to the marked chemoresistance that occurs in PDAC, thus inhibiting NF- $\mathrm{KB}$ not only will tackle the problem of PDAC development and progression, but may also attenuate chemoresistance, thereby potentially improving responses to chemotherapy.

PDAC is a complex disease that is all too often therapy-recalcitrant. Our review suggests that combination therapies targeting NF- $\mathrm{BB}$ in conjunction with either classical chemotherapy, such as gemcitabine or other targeted therapies could yield promising therapeutic strategies. Direct targeting of NF-кB still faces important challenges due to the vital role that NF- $\kappa B$ plays in normal physiological conditions. In the future, targeting nonredundant cytosolic activators of NF- $\mathrm{kB}$ instead of $\mathrm{NF}-\kappa \mathrm{B}$ itself could represent a better approach to inhibit key processes in PC. In this regard, it makes the discovery of pathway-specific novel activators of NF- $\mathrm{kB}$ a very 
attractive task $[48,49]$ for drug target identification and PDAC treatment.

\section{ACKNOWLEDGEMENTS}

The research is supported by grants $23-862-07 \mathrm{TL}$ (to TL) and 036433730102 (to TL) and, in part, by NIH grant CA-075059 to MK.

\section{REFERENCES}

1. Sen R, Baltimore D. Multiple nuclear factors interact with the immunoglobulin enhancer sequences. Cell. 1986; 46:705-16.

2. Gilmore TD. Introduction to NF-кB: players, pathways, perspectives. Oncogene. 2006; 25:6680-84.

3. Lenardo MJ, Pierce JW, Baltimore D. Protein-binding sites in Ig gene enhancers determine transcriptional activity and inducibility. Science. 1987; 236:1573-77.

4. Aggarwal B, Shishodiab S. Molecular targets of dietary agents for prevention and therapy of cancer. Science Direct. 2006; 71:1397-421.

5. Lu T, Sathe SS, Swiatkowski SM, Hampole CV, Stark GR. Secretion of cytokines and growth factors as a general cause of constitutive NF- $\kappa \mathrm{B}$ activation in cancer. Oncogene. 2004; 23:2136-45.

6. Lu T, Stark GR. Cytokine secretion and constitutive NF- $\kappa B$ in cancer. Cell Cycle. 2004; 3:1114-7.

7. Cogswell PC, Guttridge DC, Funkhouser WK, Baldwin AS Jr. Selective activation of NF-kappa B subunits

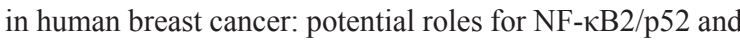
for Bcl-3. Oncogene. 2000; 19:1123-31.

8. Okayasu I, Ohkusa T, Kajiura K, Kanno J, Sakamoto S. Promotion of colorectal neoplasia in experimental murine ulcerative colitis. Gut. 1996; 39:87-92.

9. Greten FR, Eckmann L, Greten TF, Park JM, Li ZW, Egan LJ, Kagnoff MF, Karin M. IKK $\beta$ links inflammation and tumorigenesis in a mouse model of colitis-associated cancer. Cell. 2004; 118:285-96.

10. DiDonato JA, Mercurio F, Karin M. NF- $\kappa B$ and the link between inflammation and cancer. Immunol Rev. 2012; 246:379-400.

11. Kashani-Sabet M, Shaikh L, Miller JR, Nosrati M, Ferreira CM, Debs RJ, Sagebiel RW. NF- $\mathrm{BB}$ in the vascular progression of melanoma. J Clin Oncol. 2004; 22:617-23.

12. Karin M. Nuclear factor- $\kappa \mathrm{B}$ in cancer development and progression. Nature. 2006; 441:431-6.

13. Kern SE. Molecular genetic alterations in ductal pancreatic adenocarcinomas. Med. Clin. North Am. 2000; 84:691-5.

14. Hingorani SR, Petricoin EF, Maitra A, Rajapakse V, King C, Jacobetz MA, Ross S, Conrads TP, Veenstra TD, Hitt BA, Kawaguchi Y, Johann D, Liotta LA,
Crawford HC, Putt ME, Jacks T, Wright CV, Hruban RH, Lowy AM, Tuveson DA. Preinvasive and invasive ductal pancreatic cancer and its early detection in the mouse. Cancer Cell. 2003; 4:437-50.

15. Hezel AF, Kimmelman AC, Stanger BZ, Bardeesy N, Depinho RA. Genetics and biology of pancreatic ductal adenocarcinoma. Genes Dev. 2006; 20:1218-49.

16. Bardeesy N, Aguirre AJ, Chu GC, Cheng KH, Lopez LV, Hezel AF, Feng B, Brennan C, Weissleder R, Mahmood U, Hanahan D, Redston MS, Chin L, Depinho RA. Both p16 (Ink4a) and the p19(Arf)-p53 pathway constrain progression of pancreatic adenocarcinoma in the mouse. Proc. Natl. Acad. Sci. 2006; 103:5947-52.

17. Aguirre AJ, Bardeesy N, Sinha M, Lopez L, Tuveson DA, Horner J, Redston MS, DePinho RA. Activated Kras and Ink4a/Arf deficiency cooperate to produce metastatic pancreatic ductal adenocarcinoma. Genes Dev. 2004; 17:3112-26.

18. Bardeesy N, Cheng KH, Berger JH, Chu GC, Pahler J, Olson P, Hezel AF, Horner J, Lauwers GY, Hanahan D, DePinho RA. Smad4 is dispensable for normal pancreas development yet critical in progression and tumor biology of pancreas cancer. Genes Dev. 2006; 20:3130-46.

19. Hill R, Calvopina JH, Kim C, Wang Y, Dawson DW, Donahue TR, Dry S, Wu H. PTEN loss accelerates KrasG12D-induced pancreatic cancer development. Cancer Res. 2010; 70:7114-24.

20. Carrière C, Gore AJ, Norris AM, Gunn JR, Young AL, Longnecker DS, Korc M. Deletion of $R b$ accelerates pancreatic carcinogenesis by oncogenic Kras and impairs senescence in pre-malignant lesions. Gastroenterology. 2011; 141:1091-101.

21. Siegel R, Ma J, Zou Z, Jemal A. Cancer statistics, 2014. CA Cancer J Clin. 2014; 64:9-29.

22. Preis M, Korc M. Signaling pathways in pancreatic cancer. Crit Rev Eukaryot Gene Expr. 2011; 21:115-29.

23. Lowenfels AB, Maisonneuve $P$, Cavallini G, Ammann RW, Lankisch PG, Andersen JR, Dimagno EP, Andrén-Sandberg A, Domellöf L. Pancreatitis and the risk of pancreatic cancer. International Pancreatitis Study Group. N Engl J Med. 1993; 328:1433-7.

24. Korc M. Pathways for aberrant angiogenesis in pancreatic cancer. Mol Cancer. 2003; 2:8.

25. Wang W, Abbruzzese JL, Evans DB, Larry L, Cleary KR, Chiao PJ. The nuclear factor- $\kappa \mathrm{B}$ RelA transcription factor is constitutively activated in human pancreatic adenocarcinoma cells. Clin Cancer Res. 1999; 5:119-27.

26. Ling J, Kang Y, Zhao R, Xia Q, Lee DF, Chang Z, Li J, Peng B, Fleming JB, Wang H, Liu J, Lemischka IR, Hung MC, Chiao PJ. KrasG12D-induced IKK2/ $\beta$ / NF- $\kappa \mathrm{B}$ activation by IL-1a and p62 feedforward loops is required for development of pancreatic ductal adenocarcinoma. Cancer Cell. 2012; 21:105-20. 
27. Maniati E, Bossard M, Cook N, Candido JB, Emami-Shahri N, Nedospasov SA, Balkwill FR, Tuveson DA, Hagemann T. Crosstalk between the canonical NF-kB and Notch signaling pathways inhibits Ppary expression and promotes PC progression in mice. J Clin Invest. 2011; 121:4685-99.

28. Liou GY, Döppler H, Necela B, Krishna M, Crawford HC, Raimondo M, Storz P. Macrophage-secreted cytokines drive pancreatic acinar-to-ductal metaplasia through NF- $\mathrm{BB}$ and MMPs. J Cell Biol. 2013; 202:563-77.

29. Chow JY, Ban M, Wu HL, Nguyen F, Huang M, Chung H, Dong H, Carethers JM. TGF- $\beta$ downregulates PTEN via activation of NF- $\kappa \mathrm{B}$ in PC cells. Am J Physiol Gastrointest Liver Physiol. 2010; 298:275-82.

30. Shinohara H, Behar M, Inoue K, Hiroshima M, Yasuda T, Nagashima T, Kimura S, Sanjo H, Maeda S, Yumoto N, Ki S, Akira S, Sako Y, Hoffmann A, Kurosaki T, Okada-Hatakeyama M. Positive feedback within a kinase signaling complex functions as a switch mechanism for NF- $\kappa$ B activation. Science. 2014; 344:760-4.

31. Lu T, Tian L, Han Y, Vogelbaum M, Stark GR. Dosedependent cross-talk between the transforming growth factor- $\beta$ and interleukin-1 signaling pathways. Proc Natl Acad Sci U S A. 2007; 104:4365-70.

32. Wente MN, Mayer C, Gaida MM, Michalski CW, Giese T, Bergmann F, Giese NA, Büchler MW, Friess H. CXCL14 expression and potential function in PC. Cancer lett. 2008; 259:209-17.

33. Lu Z, Li Y, Takwi A, Li B, Zhang J, Conklin DJ, Young KH, Martin R, Li Y. miR-301a as an NF-kB activator in PC cells. EMBO J. 2011; 30:57-67.

34. Ma Z, Vocadlo DJ, Vosseller K. Hyper-O-GlcNAcylation is anti-apoptotic and maintains constitutive NF- $\kappa \mathrm{B}$ activity in PC cells. J Biol Chem. 2013; 288:15121-30.

35. Pahl HL. Activators and target genes of Rel/NF- $\kappa \mathrm{B}$ transcription factors. Oncogene. 1999; 18:6853-66.

36. Gilabert M, Calvo E, Airoldi A, Hamidi T, Moutardier V, Turrini O, Iovanna J. PC-Induced Cachexia Is Jak2Dependent in Mice. J Cell Physiol. 2014; 229:1437-43.

37. Döppler H, Liou GY, Storz P. Downregulation of TRAF2 mediates NIK-induced pancreatic cancer cell proliferation and tumorigenicity. PLoS One. 2013; 8:e53676doi: 10.1371/journal.pone.0053676.

38. Gilmore $\mathrm{T}$, Herscovitch $\mathrm{M}$. Inhibitors of $\mathrm{NF}-\kappa \mathrm{B}$ signaling: 785 and counting. Oncogene. 2006; 25: 6887-99.

39. Gonzales A, Orlando R. Curcumin and resveratrol inhibit nuclear factor- $\kappa \mathrm{B}-$ mediated cytokine expression in adipocytes. Nutr Metab. 2008; 5:17.
40. Qui X, Du Y, Lou B, Zuo Y, Shao W, Huo Y, Huang J, $\mathrm{Yu} \mathrm{Y,} \mathrm{Zhou} \mathrm{B,} \mathrm{Du} \mathrm{J,} \mathrm{Fu} \mathrm{H,} \mathrm{Bu} \mathrm{X.} \mathrm{Synthesis} \mathrm{and}$ identification of new 4-arylidene curcumin analogues as potential anticancer agents targeeting nuclear factor- $\kappa \mathrm{B}$ signaling pathway. J Med Chem. 2010; 53: $8260-73$.

41. Venkateswararao E, Sharma V, Yun J, Kim Y, Jung S. Antiproliferative effect of chalcone derivates through inactivation of NF- $\mathrm{KB}$ in human cancer cells. Bioorg Med Chem. 2014; 22:3386-92.

42. Priyadarsini R, Murugan R, Maitreyi S, Ramalingam K, Karunagaran D, Nagini S. The flavonoid quercetin induces cell cycle arrest and mitochondria-mediated apoptosis in human cervical cancer (HeLa) cells through p53 induction and NF- $\mathrm{kB}$ inhibition. Eur J Pharm. 2010; 649: 84-91.

43. Kobayashi T, Yoshimori A, Kino K, Komori R, Miyazawa $\mathrm{H}$, Tanuma S. A new small molecule that directly inhibits the DNA binding of NF- $\kappa$ B. Bioorg Med Chem. 2009; 7:5293-7.

44. Mulligan G, Mitsiades C, Bryant B, Zhan F, Chng WJ, Roels S, Koenig E, Fergus A, Huang Y, Richardson P, Trepicchio WL, Broyl A, Sonneveld P, Shaughnessy JD Jr, Bergsagel PL, Schenkein D, Esseltine D, Boral A, Anderson KC. Gene expression profiling and correlation with outcome in clinical trials of the proteasome inhibitor bortezomib. Blood. 2007; 109:3177-88.

45. Keifer J, Guttridge D, Ashburner B, Baldwin A. Inhibition of NF $\kappa$ B activity by thalidomide through suppression of IкB kinase activity. J Biol Chem. 2001; 276:22382-7.

46. Rao CV, Mohammed A, Janakiram NB, Li Q, Ritchie RL, Lightfoot S, Vibhudutta A, Steele VE. Inhibition of pancreatic intraepithelial neoplasia progression to carcinoma by nitric oxide-releasing aspirin in p48 (Cre/+) $\square$ LSL-Kras(G12D/+) mice. Neoplasia. 2012; 14: 778-87.

47. Streicher SA, Yu H, Lu L, Kidd MS, Risch HA. Case-control study of aspirin use and risk of pancreatic cancer. Cancer Epidemiol Biomarkers Prev. 2014; 23:1254-63.

48. Lu T, Jackson MW, Singhi AD, Kandel ES, Yang M, Gudkov AV, Stark GR. Validation-based insertional mutagenesis to identify the FBXL11 as a negative regulator of NF-kB. Proc Natl Acad Sci USA. 2009; 106: 16339-44.

49. Wei H, Wang B, She Y, Gopalan B, Miyagi M, Stark GR, Lu T. PRMT5 dimethylates R30 of the p65 subunit to activate NF- $\kappa B$. Proc Natl Acad Sci USA. 2013; 110:13516-21. 